\title{
Numerical Investigation of the Influence of Roof Fracturing Angle on the Stability of Gob-Side Entry Subjected to Dynamic Loading
}

\author{
Zhibiao Guo, ${ }^{1,2}$ Lei Zhang $\left(\mathbb{D},{ }^{2}\right.$ Zhibo Ma, ${ }^{2}$ Feixiang Zhong, ${ }^{2}$ Jingchao Yu, $^{2}$ \\ and Siming Wang ${ }^{2}$ \\ ${ }^{1}$ State Key Laboratory for Geomechanics and Deep Underground Engineering, China University of Mining and Technology, \\ Beijing 100083, China \\ ${ }^{2}$ School of Mechanics and Civil Engineering, China University of Mining and Technology, Beijing 100083, China
}

Correspondence should be addressed to Lei Zhang; zhanglei_sdjn@163.com

Received 7 December 2018; Revised 22 February 2019; Accepted 8 April 2019; Published 7 May 2019

Academic Editor: Itzhak Green

Copyright (c) 2019 Zhibiao Guo et al. This is an open access article distributed under the Creative Commons Attribution License, which permits unrestricted use, distribution, and reproduction in any medium, provided the original work is properly cited.

In order to increase the mining rate of underground coal resources, an innovative nonpillar underground coal mining approach (fracturing roofs to maintain entry (FRME)) has been widely applied in China. The effect of roof fracturing determines whether the entry can be retained successfully or not. In this work, the tail entry of 21304 panel in Chengjiao Coal Mine (China) has been considered as the test site. The coal mine is located approximately $900 \mathrm{~m}$ underground. A numerical investigation on the relationship between the entry stability and roof fracturing angle was conducted. In order to investigate the reasonable scope of roof fracturing angle under static and dynamic loadings, the double-yield model was employed to simulate the gob materials, and the input parameters of the model were calibrated meticulously using the method of inversion analysis. Furthermore, dynamic loading was applied to research the influence of fracture of hard rock strata on the entry stability. The global model was validated with the field data. The simulation results demonstrate that the reasonable scope of the roof fracturing angle is $10-20^{\circ}$, in which case the distributions of vertical stress are favorable to the stability of gob-side entry. Additionally, the dynamic responses were found to be relatively moderate. The numerical method could provide a significant reference for the design of FRME approach.

\section{Introduction}

As one of the nonrenewable resources, coal plays a significant role in China's energy strategy and accounts for approximately $60 \%$ of the total energy consumption [1]. Globally, gob-side entry retaining (GER) has widely been conducted for underground coal extraction. The conventional GER has played a positive role in improving the mining rate of coal [2]. An innovative nonpillar underground coal mining approach, through fracturing roofs to maintain entry (FRME), has been applied in tens of coal mines in China and does not involve any coal pillar or filling body between the two panels [3]. With regards to the FRME approach, the bulking gangue body is used as a rib of the tail entry after the current panel is mined out, and the entry is retained as the head entry for the next panel. A comparison of the FRME with the small-pillar mining is illustrated in Figure 1. Roof fracturing, entry roof reinforced support, and bulking gangue prevention support are the three key technologies used in FRME [4]. Roof fracturing is accomplished using directional blasting, whereas U-steel and metal net are used to achieve the aim of bulking gangue prevention. The entry roof is reinforced by the constant resistance and large deformation anchor (CRLDA) cable. Among these key technologies, the effect of roof fracturing plays a decisive role in maintaining the gob-side entry. The realization of roof collapse mainly depends on the gravity of the immediate roof and the load applied by the overlying roof. Successive roof fracturing can lead to the collapse of roof strata and break the intact rock. Then, the caving gangues will increase in volume and can be used as a rib of the entry. Therefore, a certain roof fracturing angle is important in reducing the frictional resistance on the 


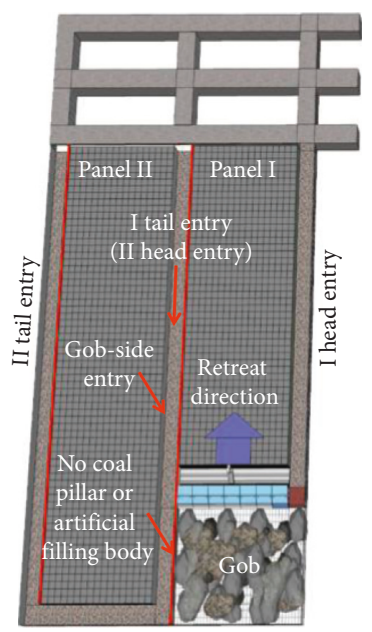

(a)

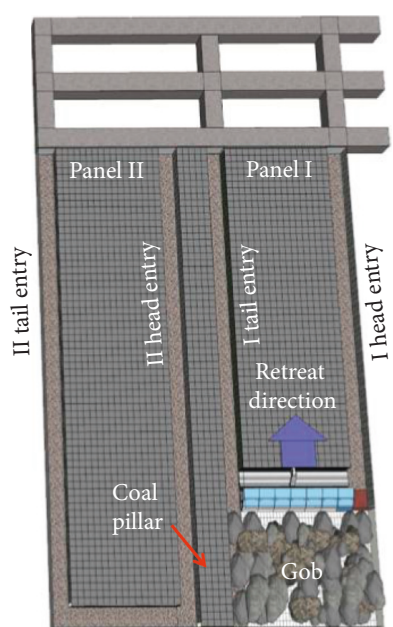

(b)

FIgURE 1: Comparison of the two underground coal mining schemes: (a) FRME approach; (b) small-pillar mining.

fracturing surface, which will affect the overall collapse of the immediate roof.

Various methods such as empirical, analytical, and testing have been used to investigate the reasonable coal pillar size [5-10]. However, as an innovative GER, studies focusing on the FRME approach are limited. He et al. [11] introduced the FRME approach in detail and studied the mechanism of FRME approach and the evolution of roof stress. The research indicated that effective caving of the gob roof is important for the deformation control of the entry. Based on a field engineering test, Wang et al. [12] introduced the technical principle and key techniques of FRME approach. The above two studies introduced the FRME approach in general. Gao et al. [13] investigated the stabilities of the entry rib by true triaxial tests under different mining conditions, and the numerical modeling showed that the roof stress transferring from gob to entry could be prevented using the FRME approach. Wang et al. [14] investigated the deformation characteristics of the gob-side entry roof and used the energy theory to propose and solve a short cantilever beam mechanical model. The results showed that the entry width and the bending of the main roof influenced the roof deformation the most. Sun et al. [15] and Guo et al. [16] investigated the key parameters of the FRME approach, involving the fracturing angle. In their models, the gob was filled with elastic materials and the viability of the input parameters was not validated. Sun et al. [17] studied the relationship between the rock-burst and mining approach through numerical simulations and reported that the FRME approach can reduce the probability of rock burst. Based on a medium-thick coal seam with compound roof, $\mathrm{Ma}$ et al. [18] investigated the strata pressure characteristics under FRME approach, and the behavioral mechanisms of mine strata were analyzed.

The dynamic failure is a threat to the safety of a coal mine, and scholars have done a lot of research on the rock-burst phenomenon $[19,20]$. Nevertheless, the dynamic loading can also be induced by sudden caving of hard rock, movement of overlying strata, and fault slip [21]. The fracturing of entry roof transforms the structure of a long cantilever beam into a short cantilever beam due to which the influence of dynamic loading on the gob-side entry becomes greater. As the underground geological conditions are complex, the stability of the entry plays a significant role due to different roof fracturing angles during its service life. Therefore, the investigations on the gob-side entry subjected to dynamic loading are of great importance to FRME approach. Wang et al. [22] researched a reasonable coal pillar size under simultaneous static and dynamic loadings through numerical simulations. Combined with the field tests, Li et al. [23] investigated the reasonable coal pillar size. The validated double-yield model was conducted to simulate the gob material, and the simulation results were found to be more realistic than those of the elastic model. However, in view of the above studies focusing on the FRME approach and studies [24-26], the dynamic effect on the entry of the FRME approach has not yet been studied, and a validated numerical model has also not been established. In order to ensure that the roof fracturing line has an appropriate angle, the current work uses FLAC3D software to study the stability of the gobside entry under static and dynamic loadings. Furthermore, a double-yield (D-Y) model for gob materials was meticulously validated, which was used to analyze the entry stability of the FRME approach under different roof fracturing angles. The innovative numerical method could provide a significant reference for the design of the FRME approach.

This paper is organized as follows: The mining and geological conditions are provided in Section 2. In Section 3, the procedure of numerical simulation is introduced, including the model generation, simulation plan, D-Y model for gob materials, dynamic loading, and verification of the global model. The simulation results are analyzed in Section 4. In Section 5, based on the results, conclusions are drawn and reported.

\section{Case Study}

2.1. Entry Stability. Coal pillars and artificial filling bodies between the gob and entry result in stress concentration 
$[27,28]$. Therefore, the entries of conventional GER easily lose stability, and the deformation of the entries becomes difficult to control. With regards to the FRME approach, the stress transmission from gob roof could be cut off due to the roof fracturing, and the stress state of the entry can be improved. With the retreating of coal seam, the gob gangues experience the dynamic evolution processes such as collapse, compaction, and stability, while the entry roof structure changes correspondingly. Based on the changes in the surrounding rock's stress state, the entry of FRME approach can be divided into four stages during the retaining of the entry. These four stages are presented in Figure 2.

(i) Stage I: after the excavation of entry, the original ground stress affects the stability of the entry.

(ii) Stage II: with the retreat of working face, the advancing pressure results in stress concentration of the entry. In this stage, the vertical stress acting on the entry increases gradually.

(iii) Stage III: with the caving of the adjacent gob roof, static loading and dynamic loading affect the stability of entry. In the early Stage III (IIIa), the immediate roof of Panel \#1 collapses along the roof fracturing line and the main roof bends simultaneously, which results in static load. In the later period (Stage III (IIIb)), the sudden caving and instability result in the collapse of thick and hard rock strata, resulting in dynamic load. On one hand, the stress of coal and rock mass will increase obviously. On the other hand, the strong vibration caused by breaking will apply dynamic load on coal and rock mass in the form of a stress wave, which will lead to instability failure of coal and rock mass system in the state of ultimate stress. The elastic energy accumulated in coal and rock mass, and the vibration energy released by the fracture of hard and thick strata will interact with each other. Therefore, the dynamic load generated in Stage IIIb will affect the stability of gob-side entry. The two types of loads may lead to severe damage of the gob-side entry. The entry is difficult to control at this moment. Figure 3 shows the schematic diagram of roof caving.

(iv) Stage IV: entry is in a stable state. As the working face continues to retreat, the influence on the gobside entry gradually decreases. The gob-side entry is finally in a stable state.

2.2. Mining and Geological Conditions. The case study was based on Chengjiao Coal Mine, which was located in Yongcheng city, Henan province, China (Figure 4(a)). Furthermore, 21304 and 21305 were the associated longwall panels and extracted the no. 2 coal seam (Figure 4(b)). The length and width of the panels were $1460 \mathrm{~m}$ and $180 \mathrm{~m}$, respectively. The mining height of the coal seam was $2.95 \mathrm{~m}$. The overburden depth of the panels reached $835-915 \mathrm{~m}$. In the upward direction, mudstone, fine sandstone, siltstone, and sandy mudstone formed the rock layers above the coal seam. In the downward direction, mudstone, siltstone, and fine sandstone formed the rock layers under the coal seam. The stratigraphy column of the test site is shown in Figure 5.

The 21304 panel was arranged with two entries, namely, the head entry and the tail entry, which had to be driven first. Using the approach of FRME, the tail entry of 21304 panel was retained as the head entry of 21305 panel with the retreat of 21304 panel. Therefore, only one entry needs to be driven during the development of 21305 panel. With a rectangular cross section, all the entries were $4.4 \mathrm{~m}$ wide and $3 \mathrm{~m}$ high.

\section{Numerical Modeling}

3.1. Global Model and Simulation Plan. Numerical software FLAC3D was used to investigate the relationship between the stability of the gob-side entry and roof fracturing angle. According to the actual mining process, the Mohr-Coulomb model in the caving zone was replaced with the D-Y model after the retreat of the coal seam. On two sides of the roof fracturing line, the Mohr-Coulomb and D-Y models were used for modeling the rock strata and gob, respectively. The models are defined in Section 3.2. The liner structural element embedded in FLAC3D was used to simulate the combined support shown in Figure 6, which was used to support the gangue rib. Table 1 lists the parameters of the liner structural element. The parameters were validated through the verification of the global model, as explained in Section 3.4.

In order to accurately represent the transmission of waves through the model, the size of the spatial unit must be less than $1 / 10-1 / 8$ of the wavelength associated with the highest frequency component of the input wave. Based on the sensitivity analysis of the model with regards to size and mesh density, the model dimension was determined to be $200 \mathrm{~m} \times 120 \mathrm{~m} \times 60 \mathrm{~m}$. The global model contains half of 21304 and 21305 panels and gob-side entry system. At the top of the model, a vertical stress of $20 \mathrm{MPa}$ was applied to simulate the overburden pressure. In addition, gravity was also applied. In the initial static condition, the four vertical planes of the model were restricted in the horizontal direction, and the vertical displacement of the bottom of the model was set to be zero. Based on the evidence obtained from the field tests, the horizontal-to-vertical stress ratio in the $x$ - and $y$-direction was approximately 1.2. The cable structural element was conducted to simulate the bolt and cable support in the gob-side entry. The spacing of the bolts was $750 \times 700 \mathrm{~mm}$. Four rows of cables were installed in the entry roof. The spacings of the cables were $1200 \times 1400 \mathrm{~mm}$ and $400 \times 1400 \mathrm{~mm}$. The relevant parameters of the cable structural element are listed in Table 2. Figure 7 shows the schematic of the global model and entry support.

In order to improve the reliability of the simulation, the mechanical properties of the rock strata were tested in a laboratory. Using the servo-controlled testing system of MTS815, a series of compression tests were conducted on rock and coal specimens. The uniaxial compressive strength, Young's modulus, and Poisson's ratio were obtained using the uniaxial compression tests. In addition, the cohesion and friction angle were obtained using the triaxial compression tests. Table 3 lists the physicomechanical parameters of the rock strata. 


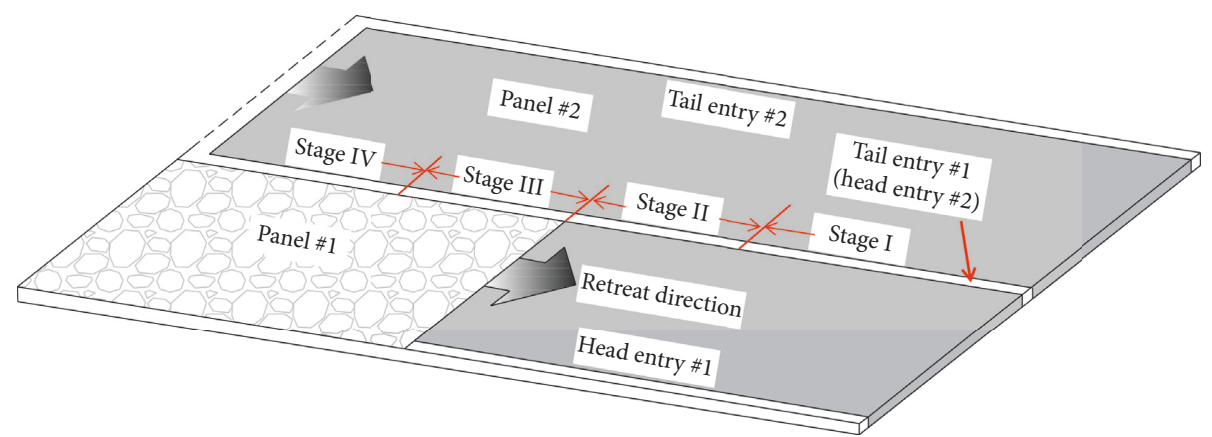

FIgURE 2: Various stages of the FRME approach for the gob-side entry.

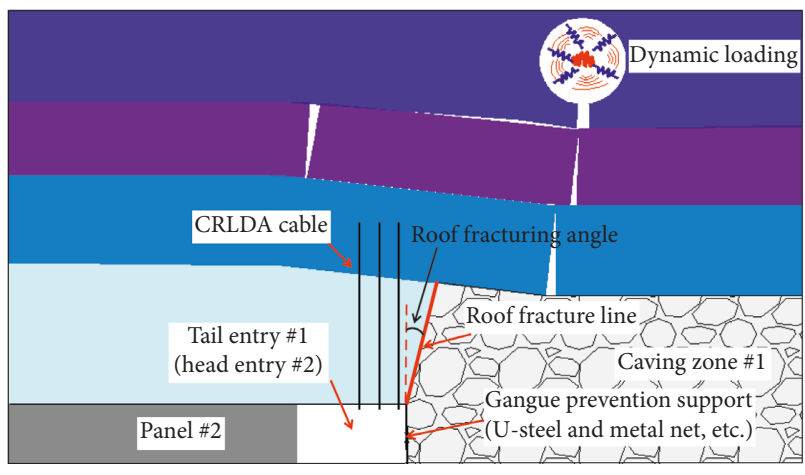

FIgURE 3: Schematic of the roof caving process.

According to the process of mining operation, the numerical model was solved in six steps (Figure 8). If the roof fracturing angle is less than $10^{\circ}$, the blasting will destroy the anchor cable around the roof fracturing line. The caving zone under different roof fracturing angles $\left(10^{\circ}, 15^{\circ}, 20^{\circ}, 25^{\circ}\right.$, and $30^{\circ}$ ) can be realized by meshing the grids in the global model. Therefore, five models were generated in the first step. The geostatic stress was applied in the second step. In the third step, the tail entry of 21304 panel was developed. After the retreating of 21304 panel in the fourth step, the dynamic loading was applied. The output of the operation was the final step of the process.

\subsection{Gob Model}

3.2.1. Gob Modeling Method Based on D-Y Model. Strain stiffening is a characteristic of gob materials. A suitable gob model is critical to the accuracy of simulation. The D-Y model has widely been used to simulate gob materials [29] and can be obtained from FLAC3D. The manual of FLAC3D states that the parameters of the D-Y model contain cap pressure and material properties. In this paper, the parameters of the D-Y model were estimated from Salamon's equation [30], and the equation can be written as

$$
\sigma=\frac{E_{0} \varepsilon}{1-\varepsilon / \varepsilon_{\mathrm{m}}},
$$

where $\sigma$ is the cap pressure applied to the gob materials, $E_{0}$ is the initial tangential modulus of the gob material, and $\varepsilon$ and $\varepsilon_{\mathrm{m}}$ are the strain and maximum strain of the gob material under applied stress, respectively. The parameters $E_{0}$ and $\varepsilon_{\mathrm{m}}$ can be expressed using the following equations [31]:

$$
\begin{aligned}
& \varepsilon_{\mathrm{m}}=\frac{b-1}{b}, \\
& \varepsilon_{\mathrm{m}}=\frac{10.39 \times \sigma_{c}^{1.042}}{b^{7.7}},
\end{aligned}
$$

where $\sigma_{\mathrm{c}}$ and $b$ are the compressive strength of the rock pieces and the bulking factor of the gangue, respectively. The bulking factor $b$ can be written as

$$
b=\frac{h_{\mathrm{cav}}+h_{\mathrm{m}}}{h_{\mathrm{cav}}},
$$

where $h_{\mathrm{cav}}$ and $h_{\mathrm{m}}$ are the caving zone height and the mining height, respectively.

Peng [32] investigated the relationship between the caving zone height and mining height. The results showed that, according to the geological conditions, the former is 2 to 8 times higher than the latter. The mining height of 21304 panel is $2.95 \mathrm{~m}$, and therefore, the height of the caving zone can be assumed to be $8 \mathrm{~m}$. Based on equation (1), the bulking factor can be estimated to be 1.37. For 21304 panel, $\sigma_{\mathrm{c}}$ was determined to be $30 \mathrm{MPa}$. Accordingly, $E_{0}$ and $\varepsilon_{\mathrm{m}}$ were calculated to be $31.84 \mathrm{MPa}$ and 0.27 , respectively. Table 4 lists the cap pressures calculated using Salamon's equation.

The stress-strain curve of the gob model should match the results obtained from Salamon's equation. In order to obtain accurate model parameters, a submodel with the dimension of $1 \mathrm{~m} \times 1 \mathrm{~m} \times 1 \mathrm{~m}$ was defined. At the top of the submodel, a velocity of $10^{-5} \mathrm{~m} / \mathrm{s}$ was applied to simulate the loading, and the four vertical planes were confined. Based on the method of trial and error, the final stress-strain curve of the numerical model was compared with Salamon's model, and the results are shown in Figure 9. It can be seen that the two curves match very well. Table 5 lists the final parameters of D-Y model.

\subsubsection{Verification of the D-Y Model for Gob Material.} Based on field data, Wilson and Carr [33] researched the distribution of gob vertical stress. The investigation noted that the vertical stress gradually increases from the gob edge to the gob center, and the vertical stress of the gob's center can reach close to the virgin stress. Figure 10 shows the 


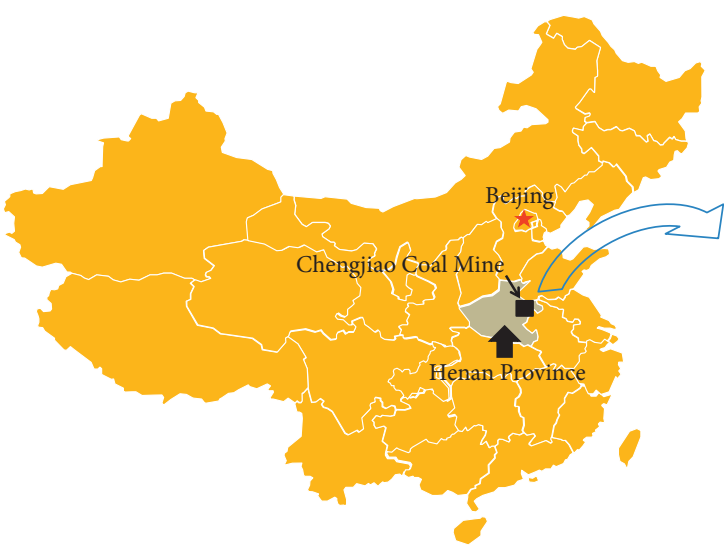

(a)

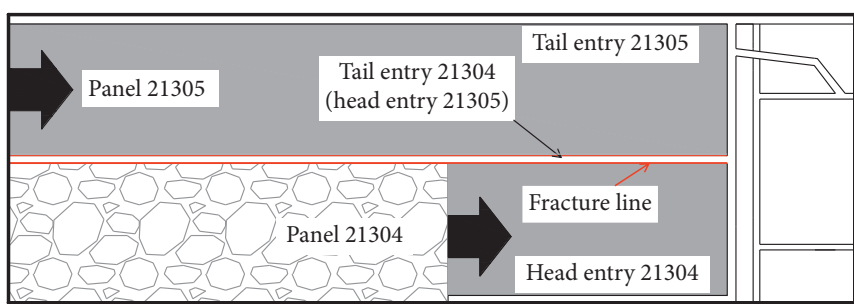

(b)

FIgURE 4: Geographical location and panel layout of the test site: (a) mine location; (b) layout of the 21304 and 21305 panels.

\begin{tabular}{|c|c|c|c|}
\hline & Lithology & Thickness (m) & Cover depth (m) \\
\hline \multirow{2}{*}{$\begin{array}{l}\nabla \nabla \nabla \nabla \nabla \\
\nabla \nabla \nabla \nabla \\
\nabla \nabla \nabla \nabla \nabla \\
\nabla \nabla \nabla \nabla \nabla \\
\nabla \nabla \nabla \nabla \nabla \\
\end{array}$} & Sandy mudstone & 18.12 & 829.17 \\
\hline & Aluminum mudstone & 4.02 & 847.29 \\
\hline & Siltstone & 3.05 & 851.31 \\
\hline \multirow{2}{*}{ 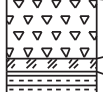 } & Sandy mudstone & 12.05 & 854.36 \\
\hline & Fine sandstone & 2.68 & 866.41 \\
\hline 年 & Mudstone & 12.32 & 869.09 \\
\hline 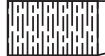 & Siltstone & 11.00 & 881.41 \\
\hline \multirow{2}{*}{ 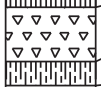 } & Sandy mudstone & 10.90 & 892.41 \\
\hline & Siltstone & 4.91 & 903.31 \\
\hline \multirow[t]{2}{*}{ 1"11"1" } & Fine sandstone & 4.23 & 908.22 \\
\hline & Mudstone & 3.10 & 912.45 \\
\hline \multirow{4}{*}{ 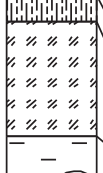 } & Coal seam & 2.95 & 915.40 \\
\hline & Mudstone & 0.86 & 916.26 \\
\hline & Siltstone & 3.26 & 919.52 \\
\hline & Fine sandstone & 23.5 & 943.02 \\
\hline
\end{tabular}

FIgURE 5: Generalised stratigraphy column of the test site.

distribution of vertical stresses in 21304 gob. It can be seen that the vertical stress increases from $0.11 \mathrm{MPa}$ to $17.5 \mathrm{MPa}$ at a distance of $80 \mathrm{~m}$ from the gob edge. Almost $78 \%$ of the in situ vertical stress $(17.5 \mathrm{MPa} / 22.5 \mathrm{MPa})$ can be recovered at the distance of $80 \mathrm{~m}$. In consideration of the large buried depth, the simulation results match those previously reported in the literature. Therefore, the calibrated parameters are suitable for application to gob materials.

3.3. Dynamic Modeling. In order to accomplish a successful dynamic analysis, the following three aspects should be considered: dynamic loading and boundary conditions, wave transmission through the model, and mechanical damping. For the overlying strata of 21304 panel, the sudden caving of the siltstone layer $(11 \mathrm{~m}$ thick and $23.14 \mathrm{~m}$ above the entry) will generate a dynamic load on the entry. Previous studies [34] have shown that, if the dynamic disturbance source is induced by roof caving, the waveform usually belongs to the single-peak waveform. Therefore, the $\mathrm{P}$-wave can be used in the simulation of the dynamic load.
Since the actual vibration velocity is difficult to monitor [35], the mine seismicity in this numerical model was based on the seismic wave theory. The wave equation [36] can be expressed as

$$
A(t)= \begin{cases}\frac{1}{2} A_{0}\left[1-\cos \left(\frac{2 \pi t}{\tau}\right)\right], & t_{0}<t<\tau+t_{0}, \\ 0, & t<t_{0}, t>\tau+t_{0}\end{cases}
$$

where $A_{0}$ is the impulse amplitude, $\tau$ is the pulse width, $t_{0}$ is action time of dynamic load, and $t=1 / f$, where $f$ is the tremor frequency.

A previous study [37] has collected some in situ data of dynamic loading, which were generated by mine seismicity in China. Table 6 lists some of these measurements, and the data were used as a reference to determine the wave properties in this simulation. In view of the previous studies [38-42], the duration of mine seismicity is approximate tens of milliseconds, whereas $10-20 \mathrm{~Hz}$ is the primary frequency, which was employed in the numerical simulation. In this 


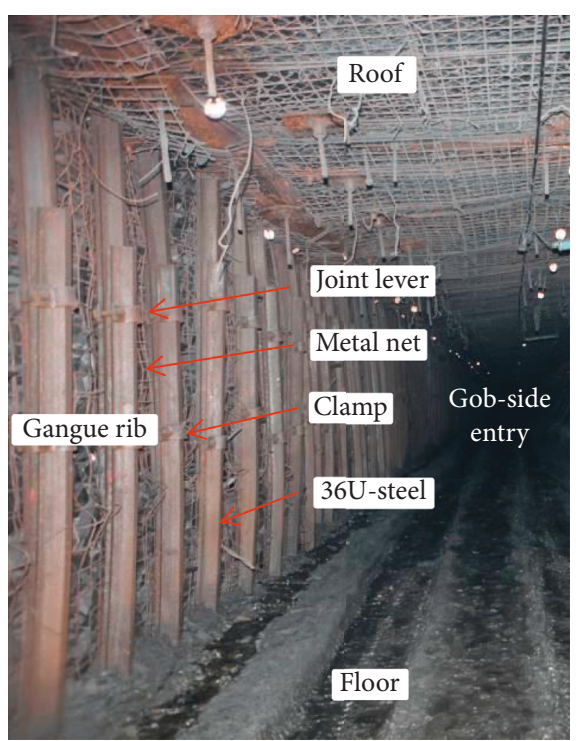

(a)

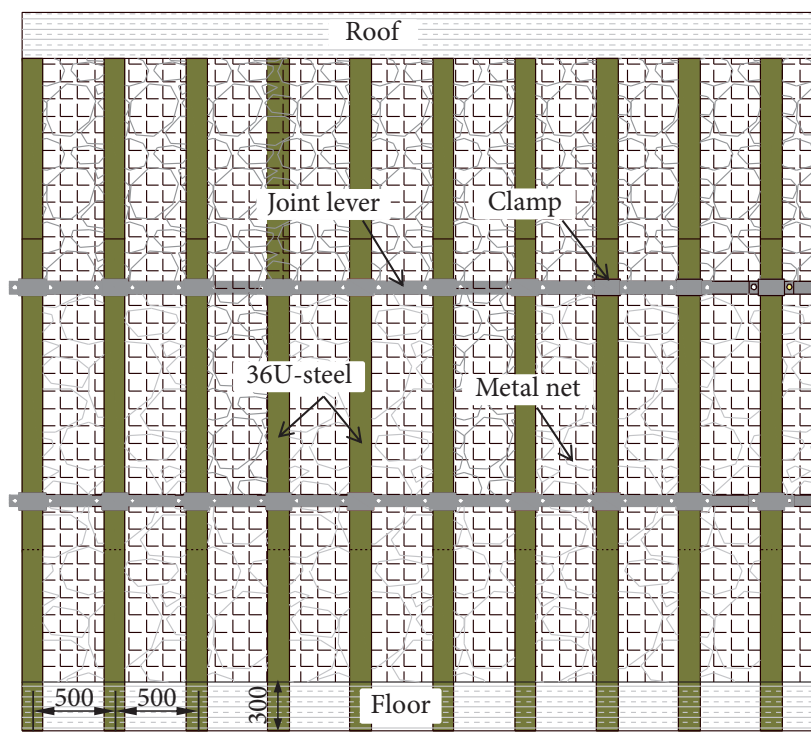

(b)

FIgURE 6: Gangue prevention support: (a) in situ schematic; (b) design schematic.

TABLE 1: Material parameters for the liner structural element.

\begin{tabular}{lcccccccc}
\hline Parameters & $\begin{array}{c}\text { Isotropic, } \\
E(\mathrm{GPa}) / \nu\end{array}$ & $\begin{array}{c}\text { Density } \\
\left(\mathrm{kg} / \mathrm{m}^{3}\right)\end{array}$ & $\begin{array}{c}\text { cs_nk } \\
(\mathrm{MPa})\end{array}$ & $\begin{array}{c}\text { cs_sk } \\
(\mathrm{MPa})\end{array}$ & $\begin{array}{c}\text { cs_ncut } \\
(\mathrm{MPa})\end{array}$ & $\begin{array}{c}\text { cs_scoh } \\
(\mathrm{MPa})\end{array}$ & $\begin{array}{c}\text { cs_scohres } \\
(\mathrm{MPa})\end{array}$ & $\begin{array}{c}\text { cs_sfric } \\
\left({ }^{\circ}\right)\end{array}$ \\
\hline Value & $25 / 0.15$ & 2500 & 800 & 800 & 4 & 4 & 2 \\
\hline
\end{tabular}

TABLE 2: Relevant parameters of the cable structural element.

\begin{tabular}{lcccccc}
\hline Type & $E(\mathrm{GPa})$ & $A\left(\mathrm{~m}^{2}\right)$ & $\rho_{\mathrm{g}}(\mathrm{m})$ & $F_{\mathrm{t}}(\mathrm{N})$ & $C_{\mathrm{g}}(\mathrm{N} / \mathrm{m})$ & \\
\hline Bolt & $200 e 9$ & $3.8 e-4$ & 0.094 & $2.6 e 5$ & $K_{\mathrm{g}}\left(\mathrm{N} / \mathrm{m}^{2}\right)$ \\
Cable & $200 e 9$ & $2.5 e-4$ & 0.089 & $7.0 e 5$ & $4.6 e 9$ \\
\hline
\end{tabular}

$E=$ Young's modulus; $A=$ cross-sectional area; $\rho_{\mathrm{g}}=$ grout circumference; $F_{\mathrm{t}}=$ tensile yield strength; $C_{\mathrm{g}}=$ grout cohesive strength per unit length; $K_{\mathrm{g}}=$ grout stiffness per unit length.

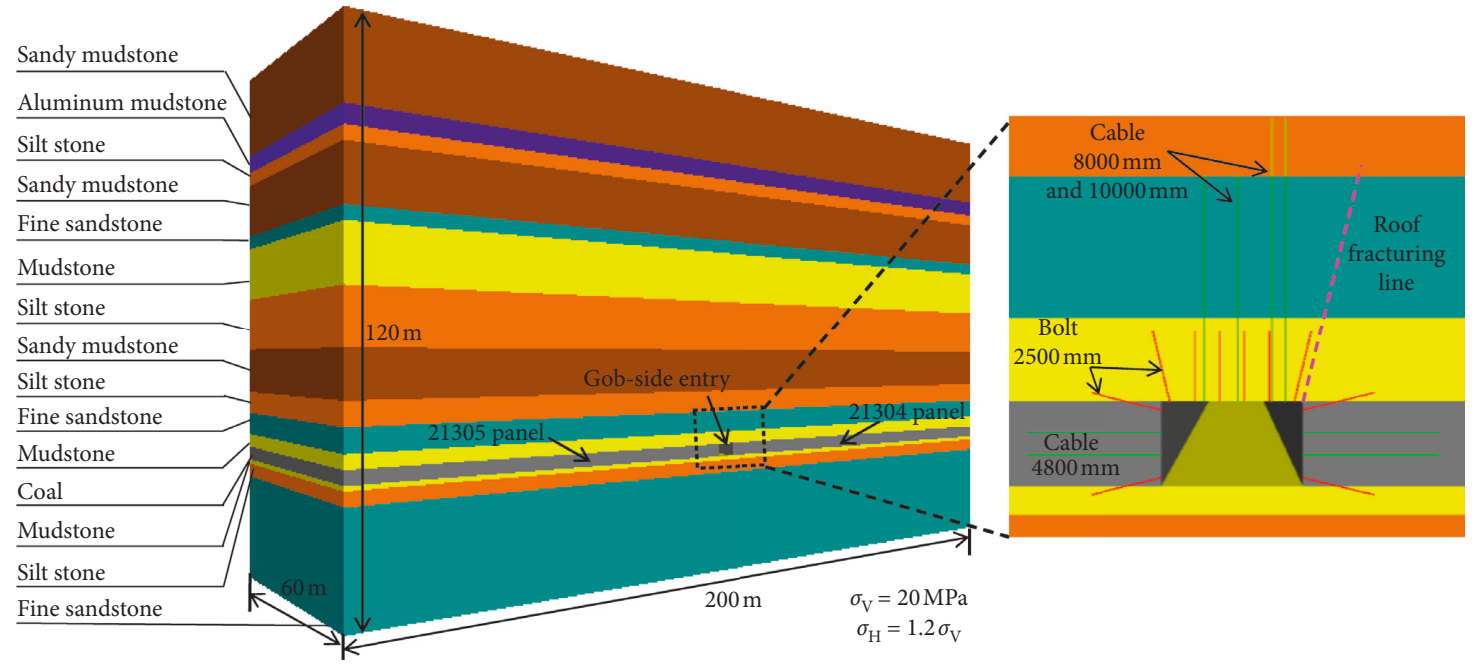

Figure 7: Schematic of the global model. 
TABle 3: Parameters of the rock strata used in the model.

\begin{tabular}{|c|c|c|c|c|c|c|}
\hline Rock strata & Density $\left(\mathrm{kg} / \mathrm{m}^{3}\right)$ & $\begin{array}{c}\text { Bulk } \\
\text { modulus (GPa) }\end{array}$ & $\begin{array}{c}\text { Shear } \\
\text { modulus }(\mathrm{GPa})\end{array}$ & $\begin{array}{l}\text { Friction } \\
\text { angle }\left({ }^{\circ}\right)\end{array}$ & Cohesion (MPa) & $\begin{array}{c}\text { Tensile } \\
\text { strength }(\mathrm{MPa})\end{array}$ \\
\hline Sandy mudstone & 2360 & 4.56 & 2.8 & 32 & 1.8 & 0.46 \\
\hline Aluminum mudstone & 2400 & 5.32 & 3.1 & 33 & 2 & 0.52 \\
\hline Siltstone & 2500 & 6.33 & 4.38 & 34 & 2.3 & 0.44 \\
\hline Sandy mudstone & 2360 & 4.56 & 2.8 & 32 & 1.8 & 0.46 \\
\hline Fine sandstone & 2600 & 8.17 & 4.95 & 38 & 2.8 & 0.63 \\
\hline Mudstone & 2250 & 1.53 & 1.26 & 30 & 1.6 & 0.42 \\
\hline Siltstone & 2500 & 6.33 & 4.38 & 34 & 2.3 & 0.44 \\
\hline Fine sandstone & 2600 & 8.17 & 4.95 & 38 & 2.8 & 0.63 \\
\hline Mudstone & 2250 & 1.53 & 1.26 & 30 & 1.6 & 0.42 \\
\hline Coal seam & 1400 & 1.42 & 1.15 & 28 & 1.5 & 0.3 \\
\hline Mudstone & 2250 & 1.53 & 1.26 & 30 & 1.6 & 0.42 \\
\hline Siltstone & 2500 & 6.33 & 4.38 & 34 & 2.3 & 0.44 \\
\hline Fine sandstone & 2600 & 8.17 & 4.95 & 38 & 2.8 & 0.63 \\
\hline
\end{tabular}

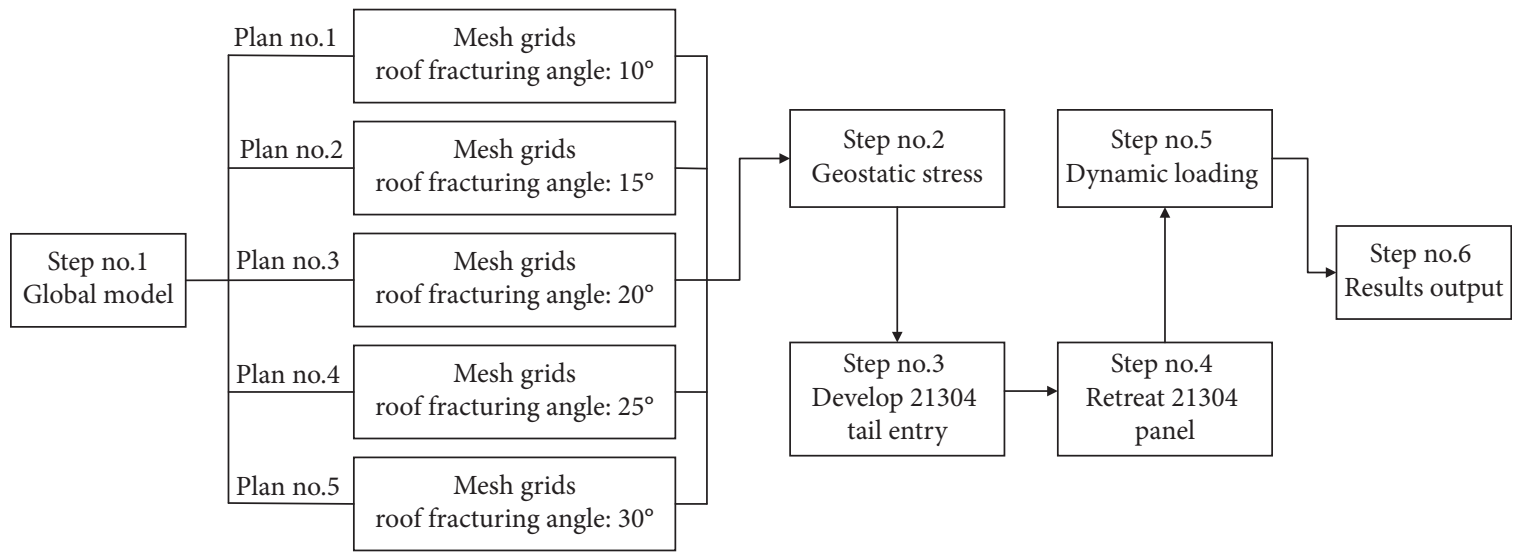

FIGURE 8: Numerical simulation plan.

TABLE 4: Calculated "cap pressures."

\begin{tabular}{lccc}
\hline Strain $(\mathrm{mm} / \mathrm{mm})$ & Stress $(\mathrm{MPa})$ & Strain $(\mathrm{mm} / \mathrm{mm})$ & Stress $(\mathrm{MPa})$ \\
\hline 0 & 0 & 0.14 & 9.26 \\
0.02 & 0.69 & 0.16 & 12.5 \\
0.04 & 1.5 & 0.18 & 17.19 \\
0.06 & 2.46 & 0.20 & 24.56 \\
0.08 & 3.62 & 0.22 & 37.83 \\
0.10 & 5.06 & 0.24 & 68.77 \\
0.12 & 6.88 & 0.26 & 223.52 \\
\hline
\end{tabular}

case study, the frequency was set to be $20 \mathrm{~Hz}$. Combined with the measured in situ entry convergence, the impulse amplitude was finally determined using the method of trial and error. The relevant parameters of the dynamic loading are listed in Table 7, in which $t_{\mathrm{d}}$ and $t_{\mathrm{c}}$ represent the dynamic loading time and simulation time, respectively.

The FLAC3D manual [43] states that the outward propagating waves will be reflected back into the model from the fixed or elastic boundaries, whereas the necessary energy radiation is not allowed. The quiet boundary and free-field boundary are the alternatives to solve the problem. In this model, the free-field boundary was applied to solve the problem of wave reflection. Rayleigh damping, hysteretic damping, and local damping are the three options available in

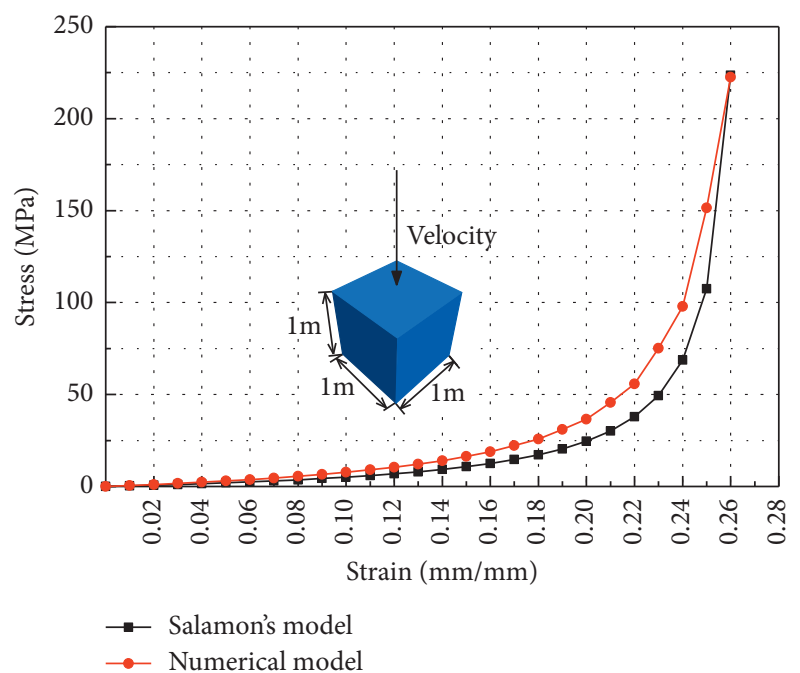

FIGURE 9: Gob stress-strain curves of numerical and Salamon's models.

FLAC3D. The specification of a frequency is not needed to local damping due to which the simpler local damping was used in the simulation. The local damping coefficient can be written as 
TABLE 5: Material parameters for the gob model.

\begin{tabular}{lccccc}
\hline Parameters & Bulk modulus $(\mathrm{GPa})$ & Shear modulus $(\mathrm{GPa})$ & Density $\left(\mathrm{kg} / \mathrm{m}^{3}\right)$ & Friction $\left(^{\circ}\right)$ & Dilation $\left(^{\circ}\right)$ \\
\hline Value & 9.36 & 7.15 & 1000 & 21 & 5 \\
\hline
\end{tabular}

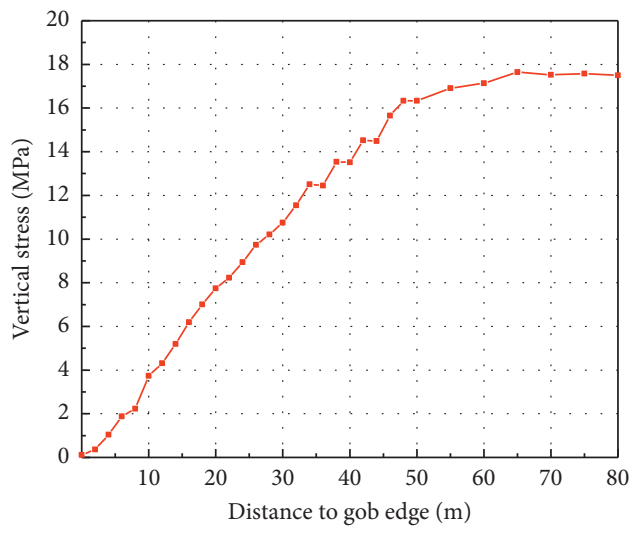

(a)

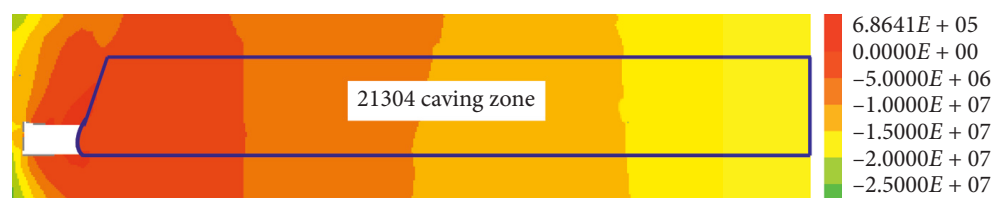

(b)

Figure 10: Vertical stress of 21304 gob after simulation step no. 4. (a) Variation trend of vertical stress in 21304 gob. (b) Simulated vertical stress distribution in 21304 gob.

TABLe 6: Statistics of the dynamic loading induced by mine seismicity.

\begin{tabular}{lcccc}
\hline $\begin{array}{l}\text { Case } \\
\text { no. }\end{array}$ & $\begin{array}{c}\text { Frequency } \\
(\mathrm{Hz})\end{array}$ & $\begin{array}{c}\text { Peak } \\
\text { velocity } \\
(\mathrm{m} / \mathrm{s})\end{array}$ & $\begin{array}{c}\text { Energy } \\
(\mathrm{J})\end{array}$ & Strain rate $\left(\mathrm{s}^{-1}\right)$ \\
\hline 1 & $2.5 \sim 15$ & $0.50 \sim 3.27$ & 50400 & $3.2 \times 10-3 \sim 1.2 \times 10^{-1}$ \\
2 & $2 \sim 18$ & $0.79 \sim 3.44$ & 22600 & $4.0 \times 10-3 \sim 1.6 \times 10^{-1}$ \\
3 & $2 \sim 18$ & $0.34 \sim 1.00$ & 8270 & $1.7 \times 10-3 \sim 4.6 \times 10^{-2}$ \\
4 & $3 \sim 25$ & $0.20 \sim 0.84$ & 1240 & $1.5 \times 10-3 \sim 5.3 \times 10^{-2}$ \\
5 & $3 \sim 28$ & $0.20 \sim 0.65$ & 895 & $1.5 \times 10-3 \sim 4.6 \times 10^{-2}$ \\
6 & $5 \sim 30$ & $0.18 \sim 0.66$ & 400 & $2.3 \times 10-3 \sim 5.0 \times 10^{-2}$ \\
\hline
\end{tabular}

$$
\alpha_{\mathrm{L}}=\pi D,
$$

where $D$ is the coefficient of the critical damping. In the dynamic analysis, $5 \%$ is a typical value for the critical damping, and therefore, $\alpha_{\mathrm{L}}=0.1571$.

3.4. Validation of the Global Model. In order to verify the reliability of global model, it is necessary to compare the field data with the model data. Several convergence stations were set at the tail entry of 21304 panel. Figure 11 shows the schematic of the on-site measurements, and the measuring instruments (lines, pegs, and tapes) are shown in the bottom right inset. The convergences of rib-to-rib and roof-to-floor were measured. The comparison between the predicted and measured convergences during the retention period of 21304 tail entry is shown in Figure 12. The solid and dotted lines represent the predicted and measured convergences, respectively. It can be seen that the simulated curves and the measured data have similar trends, which confirm the reasonability of the parameters used in the numerical model. It should be noted that the convergence of rib-to-rib is larger
TABLE 7: Relevant parameters for the dynamic loading.

\begin{tabular}{lccccc}
\hline Parameter & $f(\mathrm{~Hz})$ & $A_{0}(\mathrm{~m})$ & $t_{0}(\mathrm{~s})$ & $t_{\mathrm{d}}(\mathrm{s})$ & $t_{\mathrm{s}}(\mathrm{s})$ \\
\hline Value & 20 & 1 & 0.05 & 0.05 & 0.5 \\
\hline
\end{tabular}

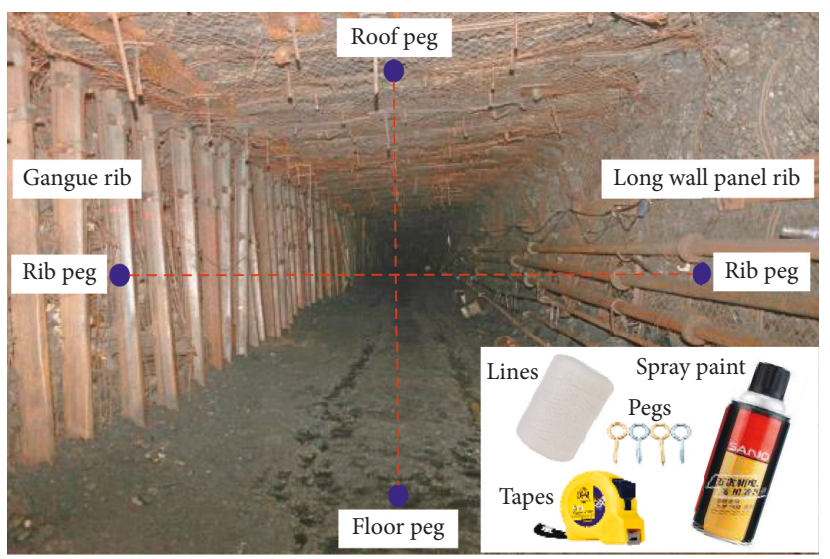

FIGURE 11: Schematic of the measurement of entry convergence.

than roof-to-floor after dynamic loading, whereas the predicted convergence is consistent with the measured data. The reliability of the model is verified. The comparison also validates the reliability of the input parameters.

\section{Model Results and Analysis}

On the basis of the model verification, the dynamic responses and the vertical stress distributions of the 21304 tail entry are studied under different roof fracturing angles. Stage III includes the static condition (IIIa) and dynamic condition (IIIb). Furthermore, the dynamic responses of the 

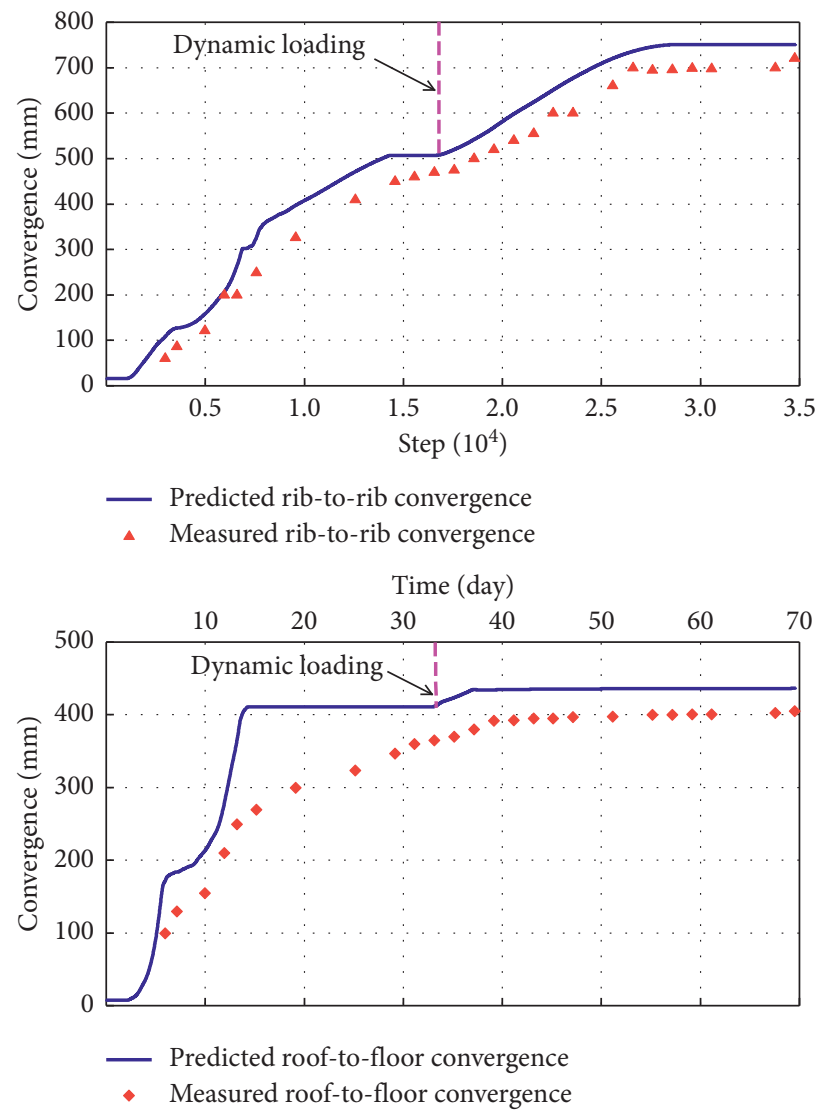

FIGURE 12: Comparison of the predicted and measured entry convergence.

21304 tail entry ribs are analyzed. Subsequently, the vertical stress distributions of the entry during the entry retention period are analyzed.

4.1. Dynamic Responses with Different Roof Fracturing Angles. Taking the deformation acceleration of the entry rib as a reference, the dynamic responses of the entry ribs are analyzed under different roof fracturing angles. As is shown in Figure 13, the $X$-axis represents different roof fracturing angles, while the $Y$-axis represents the deformation acceleration of the two ribs under dynamic loading and can reflect the magnitude of dynamic response. When the angle increases from $10^{\circ}$ to $20^{\circ}$, the deformation accelerations of the ribs in the horizontal and vertical directions are moderate. Nevertheless, the dynamic responses increase significantly when the angles reach the values of $25^{\circ}$ and $30^{\circ}$, which result in the instability of entry. The results show that a smaller roof fracturing angle is less affected by the dynamic load. It should be pointed out that the horizontal deformation acceleration at $25^{\circ}$ is greater than that at $30^{\circ}$ due to the high stress area. In general, $10-20^{\circ}$ are the reasonable angles for the FRME approach.

\subsection{Vertical Stress Distribution with Different Roof Fracturing} Angles. Figure 14 shows the vertical stress distribution during the retention period of 21304 tail entry. The blue zone represents the elastic state of the coal seam, while the yellow zone represents all the states except for the elastic state. The curves represent the changes in vertical stress in the virgin coal seam and gob. The vertical stress distributions of the three stages are shown in Figure 14, whereas Stage III is divided into static load stage (IIIa) and dynamic load stage (IIIb). The peak values of the vertical stress in different stages are labeled. Additionally, $\sigma_{\mathrm{sc}}$ and $\sigma_{\mathrm{mc}}$ are the vertical stress values of the virgin coal and caving zone, respectively.

The comparison of the vertical stress distribution shows that the peak vertical stresses with the five angles are similar in Stages I and II. With regards to the virgin coal, the peak vertical stresses in Stages I and II are approximately 35.57 MPa and 42.5 MPa, respectively. For the caving zone, the peak vertical stresses in Stages I and II are approximately $35.8 \mathrm{MPa}$ and $45 \mathrm{MPa}$, respectively. The apparent differences of vertical stresses are mainly in Stage III. When the roof fracturing angle is $10^{\circ}$ (Figure 14(a)), $\sigma_{\mathrm{sc}}$ is $58.91 \mathrm{MPa}$ in Stage IIIa. Furthermore, $\sigma_{\mathrm{sc}}$ has a tiny increase when the angle increases from $10^{\circ}$ to $20^{\circ}$ (Figure 14(c)). Meanwhile, the amplifications are $0.81 \mathrm{MPa}$ and $0.63 \mathrm{MPa}$, respectively. However, the amplification of $\sigma_{\mathrm{sc}}$ increases obviously from $20^{\circ}$ to $30^{\circ}$. The amplification of $\sigma_{\mathrm{sc}}$ is $1.83 \mathrm{MPa}$ when the angle increases from $20^{\circ}$ to $25^{\circ}$ (Figure 14(d)). As the roof fracturing angle increases from $25^{\circ}$ to $30^{\circ}$ (Figure $14(\mathrm{e})$ ) in Stage IIIa, $\sigma_{\text {sc }}$ reaches the value 


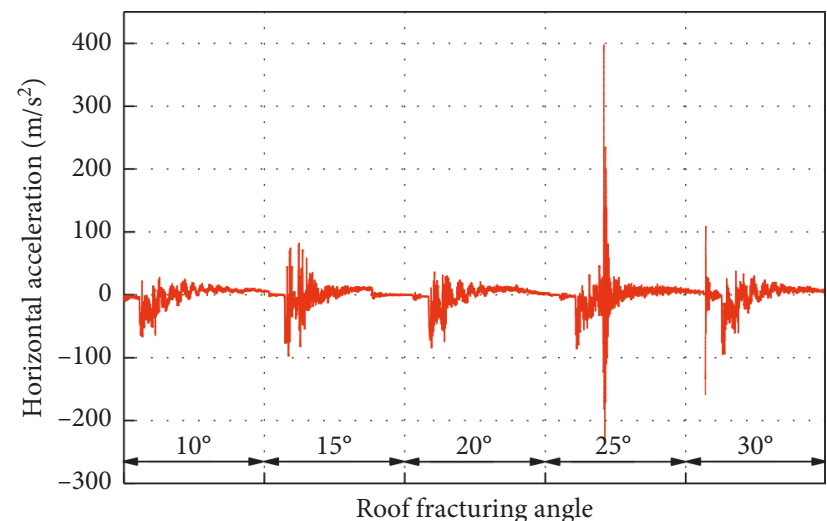

(a)

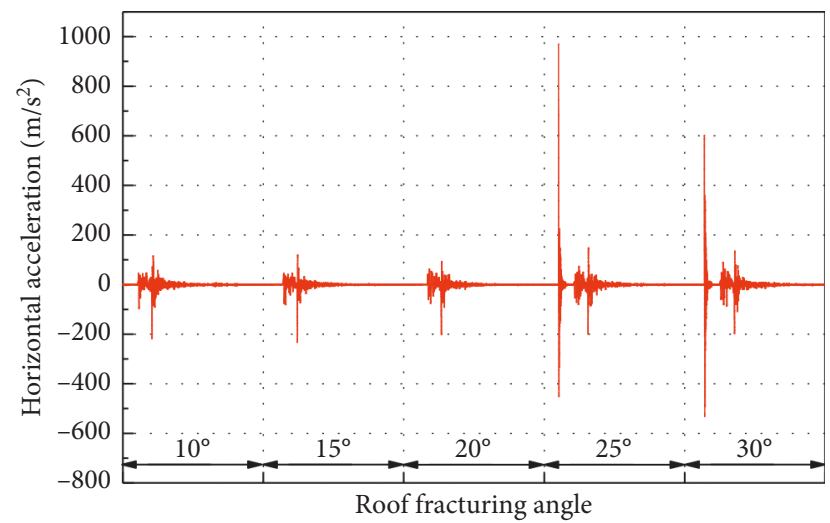

(c)

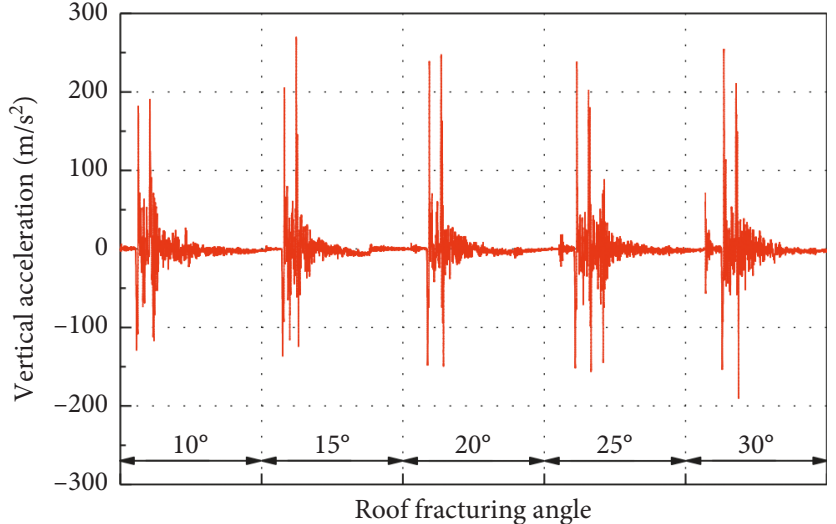

(b)

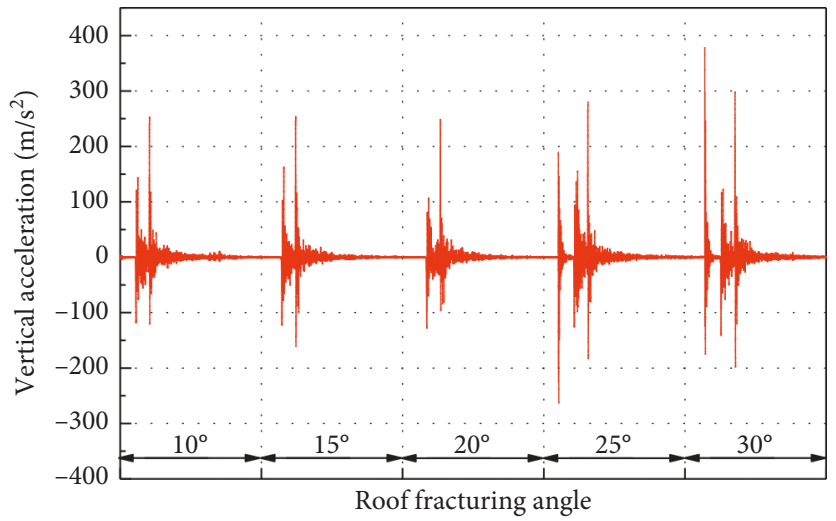

(d)

FIGURE 13: Dynamic responses of the entry with different roof fracturing angles: (a) horizontal acceleration of the gangue rib; (b) vertical acceleration of the gangue rib; (c) horizontal acceleration of the coal rib; (d) vertical acceleration of the coal rib.

of $62.18 \mathrm{MPa}$, and the amplification turns out to be $1.34 \mathrm{MPa}$. The variation in the peak vertical stress in Stage IIIb is similar to that in Stage IIIa. However, the peak values of the stresses are smaller. For the angles of $10^{\circ}$ and $15^{\circ}$, the decreases in the peak stress from Stage IIIa to Stage IIIb are $1.52 \mathrm{MPa}$ and $0.9 \mathrm{MPa}$, respectively. For the angles of $25^{\circ}$ and $30^{\circ}$, the decrease in the peak stress values from Stage IIIa to Stage IIIb are $2.01 \mathrm{MPa}$ and $2.15 \mathrm{MPa}$, respectively. The comparison of the decline in stress values indicates that the dynamic response of the entry with the roof fracturing angle of $10-20^{\circ}$ is relatively small. It should be pointed out that, with the retreat of the panel, the vertical stress distributions of the caving zone have changed significantly. From the gob edge to gob center, the vertical stress has gradually recovered. The stress distribution of the caving zone does not change much after the application of dynamic loading. According to the above analysis, the roof fracturing angles of $10-20^{\circ}$ can provide a better stress environment. Therefore, the reasonable roof fracturing angle lies between the range of $10-20^{\circ}$. Due to the large buried depth of Chengjiao Coal Mine, the underground conditions are very complex in 21304 panel. The roof fracturing angle of $10^{\circ}$ may threaten the stability of anchor cables, whereas the angle of $20^{\circ}$ increases the amount of engineering works. Considering the safety and economic aspects, the roof fracturing angle was set to be $15^{\circ}$ in the current case study.

\section{Conclusions}

In order to investigate the stability of the entry of FRME approach with regards to the roof fracturing angle, numerical simulations were employed for 21304 and 21305 panels in Chengjiao Coal Mine, China. The simulation was designed to obtain a reasonable roof fracturing angle for the gob-side entry, which was influenced by static and dynamic loadings. The conclusions and contributions of this study are listed as follows:

(1) Roof fracturing angle plays an important role in influencing the distributions of vertical stress and dynamic response. When the angle is larger than $20^{\circ}$, the peak vertical stress is large and the dynamic responses of the two ribs are relatively strong. The numerical results indicate that the reasonable values of the roof fracturing angle lie within the range of $10-20^{\circ}$. In this case, the distributions of the vertical stress are favorable to the stability of the gob-side entry, and the dynamic responses are relatively moderate. 


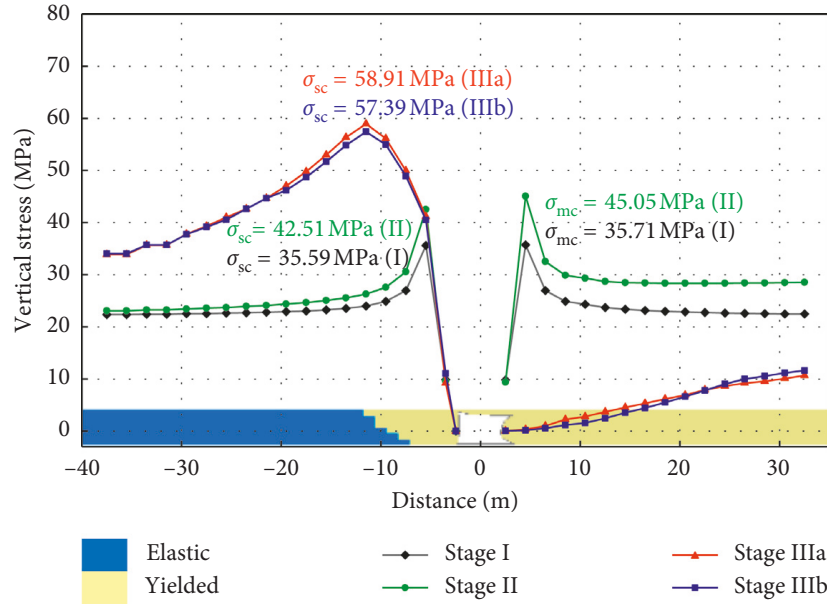

(a)

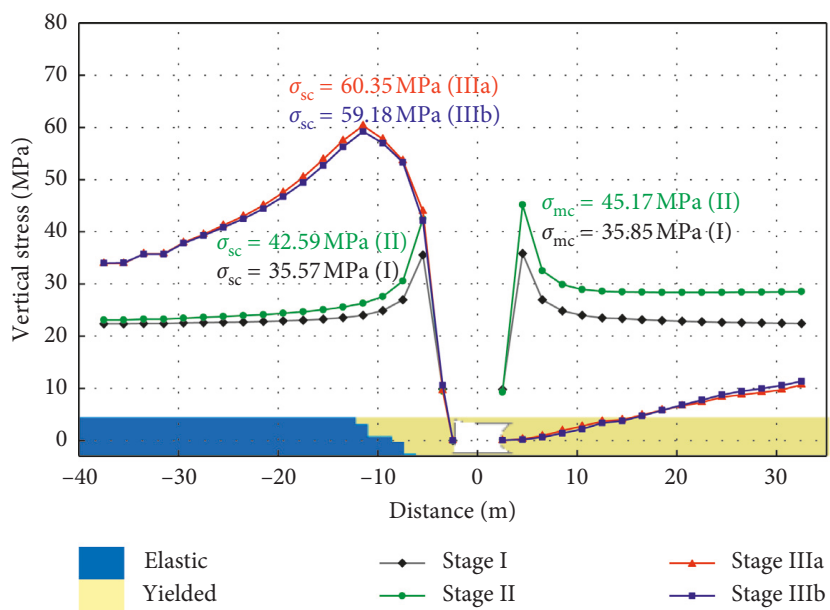

(c)

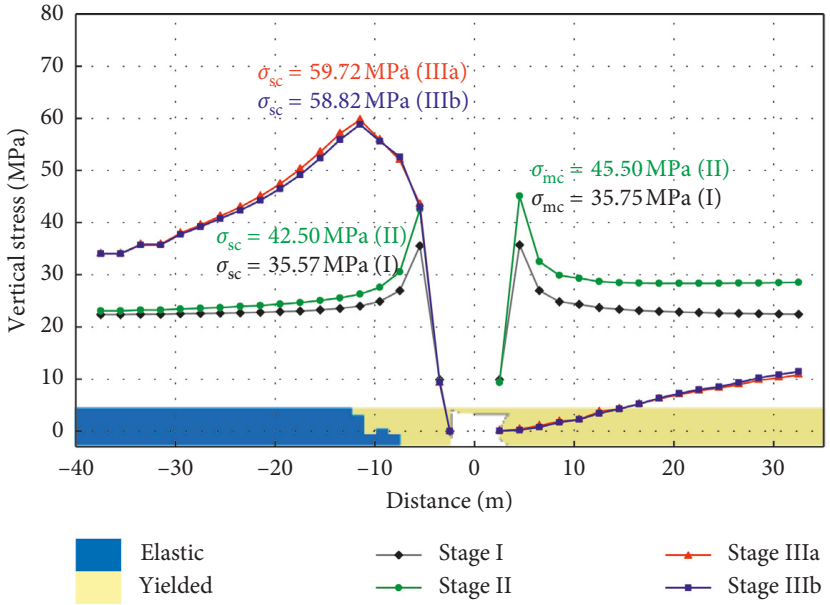

(b)

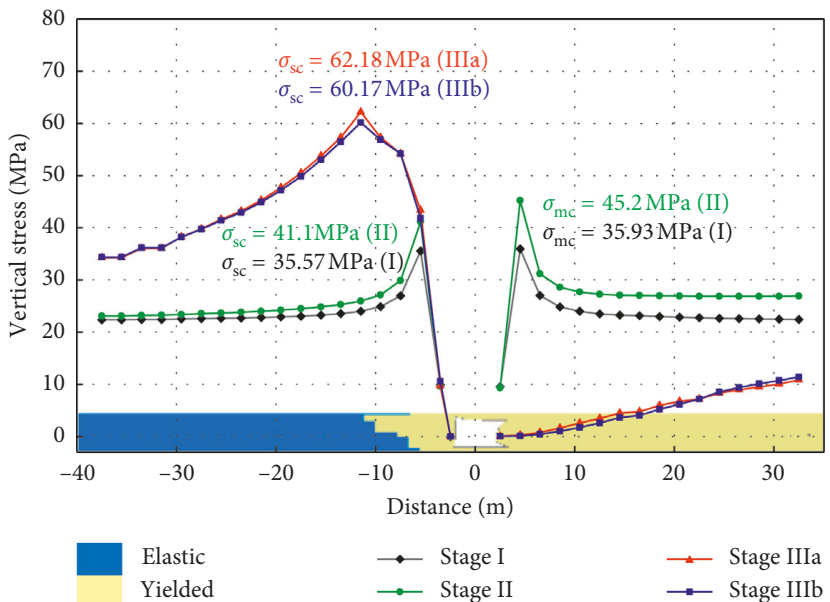

(d)

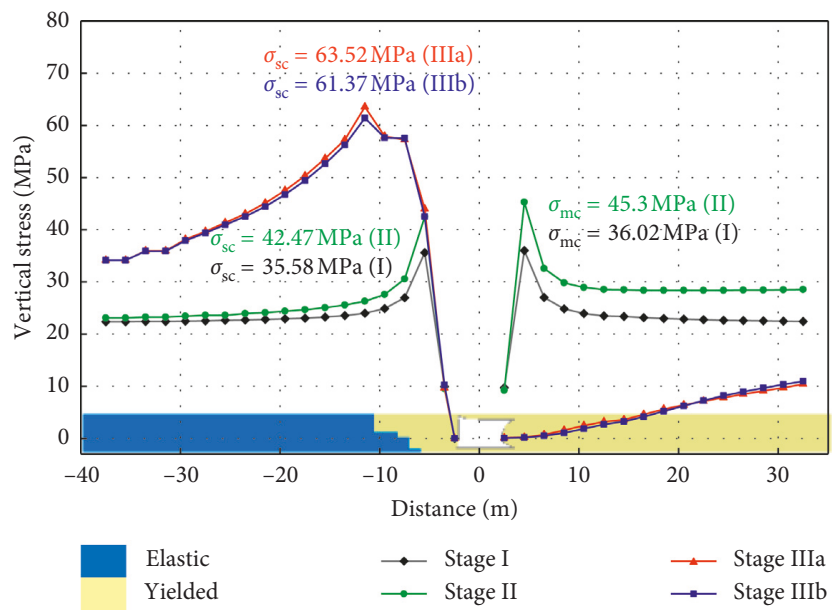

(e)

FIGURE 14: Vertical stress distribution in 21304 gob and 21305 panel with different roof fracturing angles: (a) $10^{\circ}$; (b) $15^{\circ}$; (c) $20^{\circ}$; (d) $25^{\circ}$; (e) $30^{\circ}$.

(2) The fracturing angle was $15^{\circ}$ in the field application. The field data (Figure 12) revealed that the maximum rib-to-rib and roof-to-floor convergences are approximately $700 \mathrm{~mm}$ and $400 \mathrm{~mm}$, respectively. The deformation of the gob-side entry meets the production requirement of the next working face.
(3) In order to make the numerical simulation more reliable, the gob materials were simulated using the D-Y model. Based on the method of inversion analysis, the parameters of the model were calibrated meticulously. Furthermore, the liner structural element embedded in FLAC3D was employed to 
simulate the gangue prevention support. The verification of the global model confirmed the reasonability of the gob model and liner structural element. The stability of the gob-side entry was influenced by dynamic loading and was also included in the numerical model. Additionally, the dynamic analysis was validated using the field data.

(4) The FRME approach has widely been applied in tens of coal mines in China. An appropriate design is crucial to successful implementation of the approach. As hard and thick roof is a common problem in coal mining, this paper provides a new method for the design of the roof fracturing angle while considering the effect of dynamic loading. In addition, the application of the D-Y model in FRME simulation makes the results more realistic. The modeling procedure can be used for the roof fracturing angle design in other similar coal seams.

\section{Data Availability}

All data included in this study are available upon request from the corresponding author.

\section{Conflicts of Interest}

The authors declare that there are no conflicts of interest regarding the publication of this paper.

\section{Acknowledgments}

This research was funded by the National Natural Science Foundation of China (51479195).

\section{References}

[1] M.-G. Qian, J.-L. Xu, and J.-C. Wang, "Further on the sustainable mining of coal," Journal of China Coal Society, vol. 43, no. 1, pp. 1-13, 2018.

[2] G.-C. Zhang, Y.-L. Tan, S.-J. Liang, and H.-G. Jia, "Numerical estimation of suitable gob-side filling wall width in a highly gassy longwall mining panel," International Journal of Geomechanics, vol. 18, no. 8, article 04018091, 2018.

[3] M.-C. He, Y.-J. Wang, J. Yang, P. Zhou, Q. Gao, and Y.-B. Gao, "Comparative analysis on stress field distributions in roof cutting non-pillar mining method and conventional mining method," Journal of China Coal Society, vol. 43, no. 3, pp. 626-637, 2018.

[4] M.-C. He, Y.-B. Gao, J. Yang, Z.-B. Guo, E.-Y. Wang, and Y.-J. Wang, "An energy-gathered roof cutting technique in no-pillar mining and its impact on stress variation in surrounding rocks," Chinese Journal of Rock Mechanics and Engineering, vol. 36, no. 6, pp. 1314-1325, 2017.

[5] M. Salamon and A. Munro, "A study of strength of coal pillars," Journal-South African Institute of Mining and Metallurgy, vol. 68, pp. 55-67, 1967.

[6] G. Zhang, S. Liang, Y. Tan, F. Xie, S. Chen, and H. Jia, "Numerical modeling for longwall pillar design: a case study from a typical longwall panel in China," Journal of Geophysics and Engineering, vol. 15, no. 1, pp. 121-134, 2018.
[7] L.-S. Jiang, P. Kong, J.-M. Shu, and K.-G. Fan, "Numerical analysis of support designs based on a case study of a longwall entry," Rock Mechanics and Rock Engineering, 2019.

[8] T. P. Medhurst and E. T. Brown, "A study of the mechanical behaviour of coal for pillar design," International Journal of Rock Mechanics and Mining Sciences, vol. 35, no. 8, pp. 1087-1105, 1998.

[9] L.-S. Jiang, P.-P. Zhang, L.-J. Chen et al., "Numerical approach for goaf-side entry layout and yield pillar design in fractured ground conditions," Rock Mechanics and Rock Engineering, vol. 345, no. 10, pp. 690-705, 2017.

[10] G.-C. Zhang, F.-L. He, H.-G. Jia, and Y.-H. Lai, "Analysis of gateroad stability in relation to yield pillar size: a case study," Rock Mechanics and Rock Engineering, vol. 50, pp. 1-16, 2017.

[11] M. He, Y. Gao, J. Yang, and W. Gong, "An innovative approach for gob-side entry retaining in thick coal seam longwall mining," Energies, vol. 10, no. 11, p. 1785, 2017.

[12] Q. Wang, M. He, J. Yang, H. Gao, B. Jiang, and H. Yu, "Study of a no-pillar mining technique with automatically formed gob-side entry retaining for longwall mining in coal mines," International Journal of Rock Mechanics and Mining Sciences, vol. 110, pp. 1-8, 2018.

[13] Y.-B. Gao, D.-Q. Liu, X.-Y. Zhang, and M.-C. He, "Analysis and optimization of entry stability in underground longwall mining," Sustainability, vol. 9, no. 11, p. 2079, 2017.

[14] Y. Wang, Y. Gao, E. Wang, M. He, and J. Yang, "Roof deformation characteristics and preventive techniques using a novel non-pillar mining method of gob-side entry retaining by roof cutting," Energies, vol. 11, no. 3, p. 627, 2018.

[15] X.-M. Sun, X. Liu, G.-F. Liang, D. Wang, and Y.-L. Jiang, "Key parameters of gob-side entry retaining formed by roof cut and pressure releasing in thin coal seams," Chinese Journal of Rock Mechanics and Engineering, vol. 33, no. 7, pp. 1449-1456, 2014.

[16] Z.-B. Guo, J. Wang, T.-P. Cao, L. Chen, and J. Wang, "Research on key parameters of gob-side entry retaining automatically formed by roof cutting and pressure release in thin coal seam mining," Journal of China University of Mining and Technology, vol. 45, no. 5, pp. 879-885, 2016.

[17] X.-M. Sun, G. Li, C.-W. Zhao et al., "Numerical investigation of gob-side entry retaining through precut overhanging hard roof to control rockburst," Advances in Civil Engineering, vol. 2018, Article ID 8685427, 10 pages, 2018.

[18] X. Ma, M. He, J. Wang, Y. Gao, D. Zhu, and Y. Liu, "Mine strata pressure characteristics and mechanisms in gob-side entry retention by roof cutting under medium-thick coal seam and compound roof conditions," Energies, vol. 11, no. 10, p. 2539, 2018.

[19] T.-B. Zhao, W.-Y. Guo, Y.-L. Tan, Y.-C. Yin, L.-S. Cai, and J.-F. Pan, "Case studies of rock bursts under complicated geological conditions during multi-seam mining at a depth of 800 m," Rock Mechanics and Rock Engineering, vol. 51, no. 5, pp. 1539-1564, 2018.

[20] T.-B. Zhao, W.-Y. Guo, Y.-L. Tan, C.-P. Lu, and C.-W. Wang, "Case histories of rock bursts under complicated geological conditions," Bulletin of Engineering Geology and the Environment, vol. 77, no. 4, pp. 1529-1545, 2018.

[21] L.-S. Jiang, Q.-S. Wu, Q.-L. Wu et al., "Fracture failure analysis of hard and thick key layer and its dynamic response characteristics," Engineering Failure Analysis, 2019.

[22] S.-L. Wang, S.-P. Hao, Y. Chen, J.-B. Bai, X.-Y. Wang, and $\mathrm{Y}$. $\mathrm{Xu}$, "Numerical investigation of coal pillar failure under simultaneous static and dynamic loading," International 
Journal of Rock Mechanics and Mining Sciences, vol. 84, pp. 59-68, 2016.

[23] W. Li, J. Bai, S. Peng, X. Wang, and Y. Xu, "Numerical modeling for yield pillar design: a case study," Rock Mechanics and Rock Engineering, vol. 48, no. 1, pp. 305-318, 2014.

[24] G.-F. Zhang, Y.-Q. Xu, and P. T. Ge, "Research on cut gobside entry retaining in thin coal seam of Tangshan ditch," Chinese Journal of Rock Mechanics and Engineering, vol. 47, no. 5, pp. 468-477, 2018.

[25] Y. Deng and S. Wang, "Feasibility analysis of gob-side entry retaining on a working face in a steep coal seam," International Journal of Mining Science and Technology, vol. 24, no. 4, pp. 499-503, 2014.

[26] M. He, G. Zhu, and Z. Guo, "Longwall mining "cutting cantilever beam theory" and 110 mining method in Chinathe third mining science innovation," Journal of Rock Mechanics and Geotechnical Engineering, vol. 7, no. 5, pp. 483-492, 2015.

[27] Y. L. Tan, F. H. Yu, J. G. Ning, and T. B. Zhao, "Design and construction of entry retaining wall along a gob side under hard roof stratum," International Journal of Rock Mechanics and Mining Sciences, vol. 77, pp. 115-121, 2015.

[28] G.-C. Zhang, F.-L. He, Y.-H. Lai, and H.-G. Jia, "Ground stability of underground gateroad with $1 \mathrm{~km}$ burial depth: a case study from Xingdong coal mine, China," Journal of Central South University, vol. 25, no. 6, pp. 1386-1398, 2018.

[29] M. Shabanimashcool and C. C. Li, "Numerical modelling of longwall mining and stability analysis of the gates in a coal mine," International Journal of Rock Mechanics and Mining Sciences, vol. 51, pp. 24-34, 2012.

[30] M. Salamon, "Mechanism of caving in longwall coal mining," in Rock mechanics contributions and challenges: proceedings of the 31st US symposium on rock mechanics, pp. 161-168, Golden, Colorado, 1990.

[31] H. Yavuz, "An estimation method for cover pressure reestablishment distance and pressure distribution in the goaf of longwall coal mines," International Journal of Rock Mechanics and Mining Sciences, vol. 41, no. 2, pp. 193-205, 2004.

[32] S. S. Peng, Longwall Mining, Peng SS publisher, Morgantown, WV, USA, 2nd edition, 2006.

[33] A. Wilson and F. Carr, "A new approach to the design of multientry developments of retreat longwall mining," in Proceedings of the 2nd International Conference on Ground Control in Mining, pp. 1-21, Morgantown, WV, USA, 1982.

[34] G.-A. Zhu, L.-M. Dou, Y. Liu et al., "Dynamic behavior of fault slip induced by stress waves," Shock and Vibration, vol. 2016, Article ID 4386836, 13 pages, 2016.

[35] A.-Y. Cao, Research on Seismic Effort of Burst and Failure of Coal-Rock Mass Associated with Mining and its Application, China University of Mining and Technology, Xuzhou, China, 2009.

[36] Z.-Y. Wang, L.-M. Dou, J. Li, K. Kang, and L.-F. Feng, "Numerical investigation of damage risks of roadway surrounding rocks under oblique incident dynamic loads," Shock and Vibration, vol. 2017, Article ID 6298372, 13 pages, 2017.

[37] J. He, Research of Mining Dynamic Loading Effect and Its Induced Rock Burst in Coal Mine, China University of Mining and Technology, Xuzhou, China, 2013.

[38] W.-Y. Guo, T.-B. Zhao, Y.-L. Tan, F.-H. Yu, S.-C. Hu, and F.-Q. Yang, "Progressive mitigation method of rock bursts under complicated geological conditions," International Journal of Rock Mechanics and Mining Sciences, vol. 96, pp. 11-22, 2017.
[39] Y. Pan and Z.-Q. Wang, "Fold catastrophe model of rockburst in narrow coal pillar," Rock and Soil Mechanics, vol. 25, pp. 23-30, 2004.

[40] Y. Jiang, H. Wang, S. Xue, Y. Zhao, J. Zhu, and X. Pang, "Assessment and mitigation of coal bump risk during extraction of an island longwall panel," International Journal of Coal Geology, vol. 95, no. 2, pp. 20-33, 2012.

[41] P. Wang, L.-S. Jiang, J.-Q. Jiang, P.-Q. Zheng, and W. Li, "Strata behaviors and rock burst-inducing mechanism under the coupling effect of a hard, thick stratum and a normal fault," International Journal of Geomechanics, vol. 18, no. 2, article 04017135, 2018.

[42] W.-Y. Guo, Y.-L. Tan, F.-H. Yu et al., "Mechanical behavior of rock-coal-rock specimens with different coal thicknesses," Geomechanics and Engineering, vol. 15, no. 4, pp. 1017-1027, 2018.

[43] Itasca, Dynamic Analysis, Version 3.1, Users Guide, Minneapolis, MN, USA, 2007. 


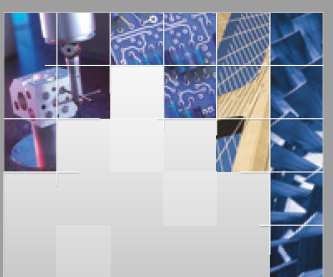

\section{Enfincering}
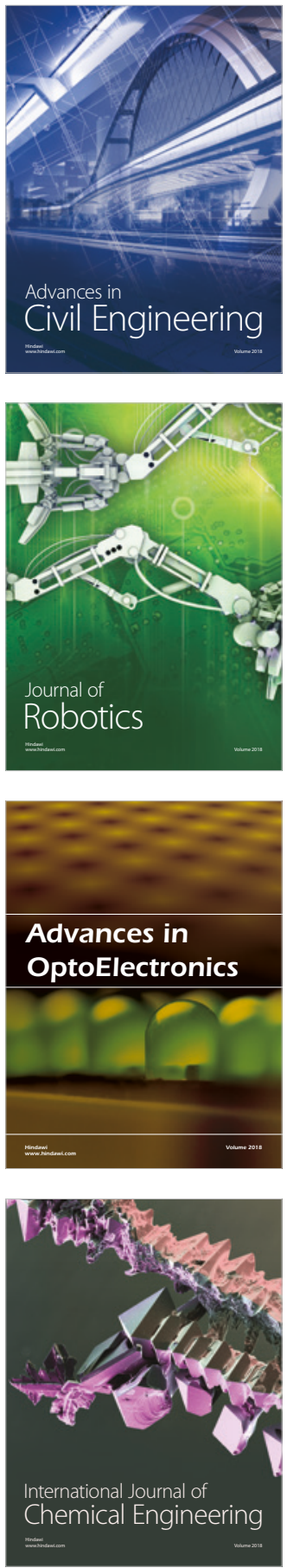

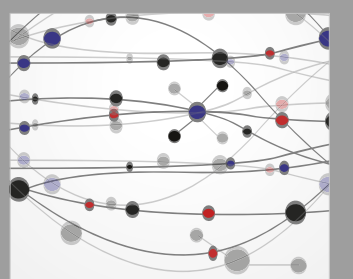

\section{Rotating \\ Machinery}

The Scientific World Journal

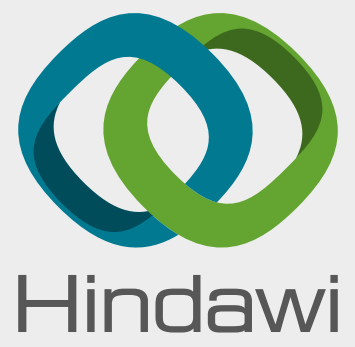

Submit your manuscripts at

www.hindawi.com
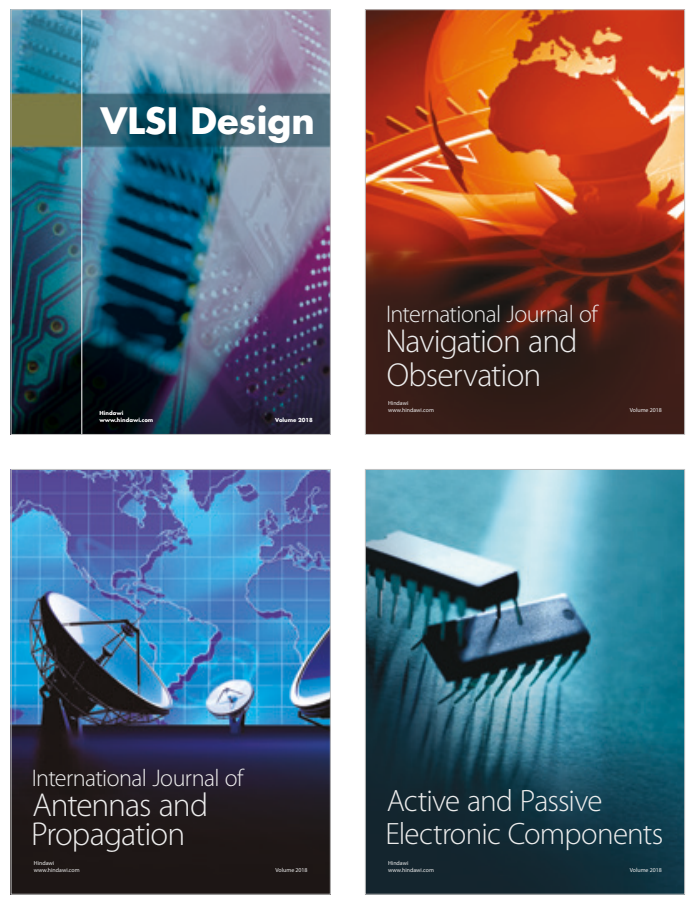
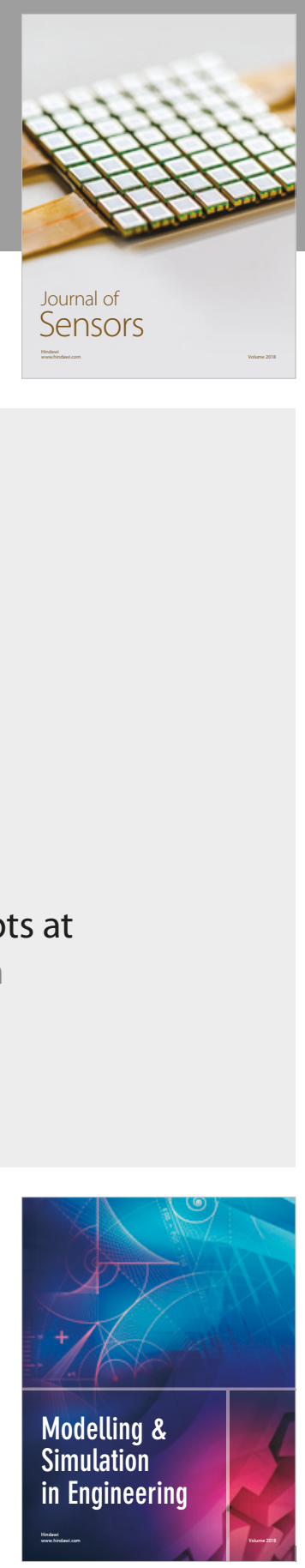

\section{Advances \\ Multimedia}
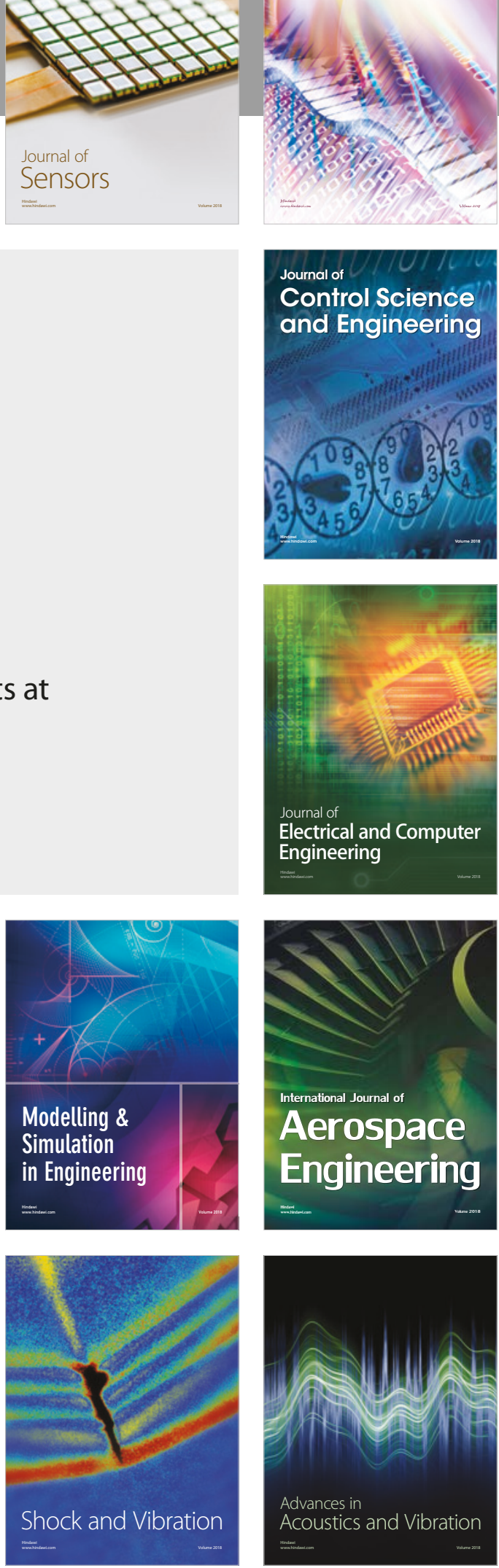